\title{
Ahmadiyah, conflicts, and violence in contemporary Indonesia
}

\author{
Nina Mariani \\ Nina Mariani Noor, SitiSyamsiyatun, JB. Banawiratma \\ Inter Rel igious Stud ies, ICRS Universitas Gadjah Mada \\ E-mail:nina.mariani@yahoo.co.id
}

\begin{abstract}
This article examines conflicts and violence experienced by Ahmadiyah community in Indonesia after reformasi era. In spite of diversities among Muslims in Indonesia, Ahmadiyah (Jemaat Ahmadiyah Indonesia) has been experiencing some forms of violence both from other Muslims and government. The number of violence has risen dramatically after the issuing second fatwa from Majelis Ulama Indonesia in 2005 and the Joint Ministerial Decree (SKB) on Ahmadiyah. Those forms of violence are issuing decree on banning Ahmadiyah, sealing the mosques and banning of doing religious activities, and mobbing the mosques and houses, including killing. Furthermore, this paper argues that Indonesia's goverment does not take its responsibility to protect its people particularly from minorities groups, even some local governments also do violence towards Ahmadiyah community.
\end{abstract}

Artikel ini membahas konflik dan kekerasan yang dialami oleh komunitas Ahmadiyah di Indonesia setelah masa reformasi. Walaupun Muslim di Indonesia sangat beragam, Jemaat Ahmadiyah Indonesia mengalami beberapa bentuk kekerasn baik dari Muslim yang lain maupun dari pemerintah. Jumlah kekerasna yang menimpa mereka meningkat tajam setelah dikeluarkannya fatwa sesat kedua dari MUI pada tahun 2005 dan Surat Keputusan Bersama (SKB) tiga menteri 
mengenai Ahmadiyah. Berbagai bentuk kekerasan yang menimpa mereka yaitu pengeluaran peraturan pelarangan keberadaan Jemaat Ahmadiyah di berbagai provinsi, penyegelan masjid dan pelarangan melakukan aktifitas keagamaan, penyerangan masjid- masjid dan rumah-rumah warga Ahmadiyah, bahkan pembunuhan. Selain itu, pemerintah pusat sepertinya tidak melaksanakan kewajibannya untuk melindungi warganya, terutama dari kalangan minoritas bahkan beberapa pemerintah lokal justru melakukan kekerasan terhadap warga Ahmadiyah di daerahnya.

Keywords: Ahmadiyah; Conflict; Violence; Persecution; Government

\section{Introduction}

Indonesia is well known for its people diversities. Indonesia, based on its constitution, is neither an Islamic state nor the secular one, but a religious state in which every citizen should have a religion to adhere. There are six religions officially recognized and facilitated by the State in Indonesia: Islam, Protestantism, Catholicism, Hinduism, Buddhism, and Confucianism. Indonesia also has the biggest Muslim community in the world. In 2010, out of Indonesia's population, there are 207, 176,162 Muslims, it is about $87.18 \%$ from all Indonesians ${ }^{1}$.

Religion is not only a binding power which bound the society but also as a source of conflicts and disputes. ${ }^{2}$ In terms of religious teachings, every religion followers usually believe that they have the truth and obligation to spread their beliefs. When one's beliefs are confronted with others, then there is a possibility of conflicts. It happens since in every religion's proliferation needs resources which in fact are very limited so that there are competitions. Religion is a belief system owned

${ }^{1}$ See http://sp2010.bps.go.id/index.php/site/tabel?search-tabel= Penduduk+ Menurut+ Kelompok+Umur+dan+Agama+yang+Dianut\&tid=320\&search-wilayah=Indonesia\& wid=0000000000\&lang=id, accesed February 20 2012.

${ }^{2}$ Nurcholish Madjid, "Agama dan Masyarakat", in AW Widjaya (Ed.), Manusia Indonesia, Individu, Keluarga dan Masyarakat, Jakarta: Akademik Pressindo, 1986. 
by an individual which involved emotions and individual thoughts and is actualized in religious actions like ceremony, worship and good deeds in an individual, a group, or a society social which involve part or entire society. ${ }^{3}$ Therefore, as a religious nation, religion was not only a source of people's aspirations but also one of the major sources of conflict in the first two decades of Indonesian history. ${ }^{4}$

Many conflicts occured in Indonesia are not only because of religious matters, but we do admit that religion is usually claimed by conflicting groups to legitimize their actions or to build solidarity within their group in dealing with other group. And it also makes the conflict lasts longer if theological matter is the reason for the conflicts.

Based on research data from Samsu Rizal Panggabean, religious conflicts or conflicts and violence carrying religious nuances emerged often in the last decade. From 1990-2008, there were 832 religious conflicts. From those, 285 (34\%) were in peaceful actions and 547 (66 $\%)$ were in violent actions. ${ }^{5}$ Indeed conflicts with violence rise dramatically in recent time.

What Panggabean means by religious conflict is "conflicts that relate to values, claim and identity which involve religious issues or issues which wrapped in religious slogan and expressions". Furthermore, Panggabean, in his study, differentiated six religious issues which caused religious conflicts in Indonesia. Firstly, moral issues such as gambling, consuming alcoholic beverages or drugs, immoral actions, prostitution,

3Parsudi Suparlan, preface in Roland Robertson (ed.), Agama Dalam Analisa dan Interpretasi Sosiologi, Jakarta: Rajawali Press, 1986.

${ }^{4}$ Mark Woodward, "Religious Conflict and the Globalization of Knowledge in Indonesian History", in Linell. E. Cady and Sheldon W. Simon (eds.), Religion and Conflict in South and Southeast Asia: Disrupting Violence, London: Routledge, 2007.

${ }^{5}$ Samsu Rizal Panggabean, et. al., "The Patterns of Religious Conflict in Indonesia (19902008)", Studia Islamika, Indonesian Journal for Islamic Studies, vol 17, Number 2 (2010): 239298. 
pornography or porno-action. Secondly, sectarian issues relate to disagreement on the religious interpretation or understanding about leadership in a religious community. Thirdly, communal issues include disputes and aggression between different religious group in communities like disputes between Muslims and Christians. Clashes that involve religious issues such as defamation issue like the caricature of the Prophet Muhammad can also be categorized in this category. Fourthly, terrorism issues include any act of terror targeting religious groups or the property of other religious groups, foreign citizens and the property of foreign governments is in the next. Finally, religious-political issues include denunciation on the West or other foreign governments and opposition against western ideologies and cultures, and for the rest that are not mentioned in those five categories. ${ }^{6}$

Since Muslims are the majority yet the most diverse, conflicts among Muslims seem to occur more frequently in Indonesia. Furthermore, opportunities for religious expression which are more open after the reformasi era also contribute to conflicts among Muslims. If in the past during New Order Regime, the government tended to harmonize people by suppressing the freedom of expressing their religious views, now after the reformasi era, the government seems to give more freedom to express it even sometimes let people express their religious expression by suppressing others.

Based on the above background, in this paper I would like to discuss conflicts that happen among Muslims in Indonesia, particularly conflicts on theological matters that involved Ahmadiyah community after reformasi era?.

\footnotetext{
${ }^{6}$ Panggabean, et. al., "The Patterns of Religious Conflict"..., 247.

${ }^{7}$ See Ihsan Ali Fauzi, Rudy Harisyah Alam, Samsu Rizal Panggabean, "Pola-Pola Konflik Keagamaan di Indonesia (1990-2008)", aporan Penelitian. Yayasan Wakaf Paramadina, Magister Perdamaian dan Resolusi Konflik, Universitas Gadjah Mada (MPRK UGM), The Asia Foundation
} 
This paper consists of six parts. Introduction explains the background of conflicts in Indonesia, and the second part discusses the diversity and categorization among Muslims in Indonesia, after that, I will discuss the MUI and its fatwas that concern with heresy and deviants on Ahmadiyah community. Furthermore, I will elaborate the existence of Ahmadiyah in Indonesia and the conflicts and violence happened to them. Finally I will conclude the paper in the concluding remarks part.

\section{Diversities among Muslims in Indonesia}

Although Islam seems to be monolithic in term of doctrinal body, its form and expression vary from one Muslim to another, from one group to other group. Muslims in Indonesia are very diverse in fact. Therefore, when we talk about Islamic groups and schools in Indonesia, we will find many.

There are many categorizations made by scholars on Muslim Indonesia. While Geertz, based on his field research, has categorized Muslims in Java in three categories, priyayi, santri (devout Muslim) and abangan (statistical Muslims). ${ }^{8}$ Rickleff in his research found out that most Muslims now categorize themselves as santri. ${ }^{9}$

Zaenal Abidin Bagir and Suhadi Cholil, in their research on pluralism in Indonesia ${ }^{10}$ show that based on some surveys on the religiosity of

(TAF), 2009, 14-15. This research found out that religious conflicts was going up during transition period after the fall The New Order Era and in the middle of the Susilo Bambang Yudhoyono, meaning from 1998 - 2008. Whereas, in the New Order Era there were only small numbers of religious conflicts.

${ }^{8}$ see Clifford Geertz, The Religion of Java, New York: Free Press, 1960.

${ }^{9}$ See Ricklefs, "Religion, politics and social dynamics in Java: Historical and contemporary rhymes", presented as keynote speech in Indonesia Update (7 September 2007), Australia.

${ }^{10}$ See Zainal Abidin Bagir and Suhadi Cholil, Potret Pluralisme di Indonesia: Kajian Literature Atas Wacana dan Praktik Pluralism 1998-2007, Center of Religious and Cultural Studies Gadjah Mada University. 
Muslims in Indonesia both in national and international level, their religiosity compare to other countries is quite high. This religiosity relates to theological faith that Islam is the only true religion. Besides that, based on Gallup Poll (2008), in the last five years, for Muslims in Muslim countries, religion is an important part in their life and they expressed that "Islam as their identity sign, meaning and guidance source and important for their progress."

According to Zuly Qodir ${ }^{11}$ and Syarif Hidayatullah ${ }^{12}$, there are several groups in Muslims Indonesian configuration. Firstly, the reforming Islam, who sees Islam not as an empty entity in time and space but as something actual and dynamic. Therefore, there is a need to do renewal continuously. There are many scholars who can be involved in this category. We can mention Nurcholish Madjid, Djohan Effendi, Ahmad Wahib and Abdurrahman Wahid, Moeslim Abdurrahman, Masdar F. Mas'udi, Kuntowijoyo, Amien Rais, Ahmad Syafi'I Ma'arif, Amin Abdullah, Ulil Abshar Abdalla, Lutfi Asyaukani, Musdah Mulia, Nassarudin Umar, Hussein Muhammad and more.

Jaringan Islam Liberal (JIL) can be involved in this group. JIL is trying to interpret Islam based on some principles, like opening ijtihad from any dimensions of Islam, prioritizing ethical religiously spirit than text literally meaning, believing on relative, open, and plural truth, siding with the minority and the oppressed, believing in religious freedom, separating the worldly and the belief authority. ${ }^{13}$

The second is retraditionalizing (indigenization) Islam in which they practice Islamic teachings in a modern way without leaving the culture

${ }^{11 Z u l y}$ Qodir, Gerakan Sosial Islam: Manifesto Kaum Beriman, Yogyakarta: Pustaka Pelajar, 2009, 88-94.

${ }^{12}$ Syarif Hidayatullah, Islam 'isme-isme', Aliran dan Paham Islam di Indonesia, Yogyakarta, Pustaka Pelajar, 2010, 50-51.

${ }^{13}$ http://islamlib.com/id/halaman/tentang-jil 
that they embraced ${ }^{14}$. The original idea was launched by $\mathrm{KH}$. Abdurrahman Wahid (Gus Dur) ${ }^{15}$. According to Rahmat ${ }^{16}$, there are several characteristics in this indigenized Islam, which are contextual, tolerant, respecting tradition, liberative and progressive. This indigenized Islam is kind of countering "authentic Islam" and "Islamic political identity" which want to make arabization on Islam in Indonesia. Indigenization Islam gives an opportunity in interpreting Islam in many ways since Islam is not a mono-interpreted but a poly-interpretable religion. Islam which is practiced in Middle-East is not the only true Islam. Muslims who belong to this group, are particularly from NU and youth $\mathrm{NU}^{17}$.

Thirdly is politizing Islam. Muslims who involve in this group tend to have a pragmatic ideology to gain a political power. They usually utilize Islamic symbols to reach their purposes for example by persuading the implementation of sharia, establishing Islamic political party, Islamic caliphs, and shura other than democracy. Actually, this group is not a dominant group but their propaganda makes them as if they are dominant, as they manipulate the publics using Islamic symbols. They exist in Islamic political parties such as PKS, PPP, PBB, PBR. ${ }^{18}$

Qodir $^{19}$ also mentions about borguising Islam that means Islamic escapism in forms of city Sufism. This phenomenon can be seen from the mushrooming of majlis dzikir which involved middle-class and they usually perform dzikir led by an ustadz and cry together. Those who

${ }^{14}$ Zuly Qodir, Gerakan Sosial Islam..., 89.

${ }^{15}$ Syarif Hidayatullah, Islam 'isme-isme'..., 50-51.

${ }^{16} \mathrm{M}$. Imdadun Rahmat, et. al. Islam Pribumi Mendialogkan Agama Membaca Realitas, Jakarta: Penerbit Erlangga, 2003.

${ }^{17}$ Syarif Hidayatullah, Islam 'isme-isme'.., 50-51.

${ }^{18 Z}$ Zuly Qodir, Gerakan Sosial Islam..., 90. PKS (Partai Keadilan Sejahtera), PPP (Partai Persatuan Pembangunan), PBB (Partai Bulan Bintang), PBR (Partai Bintang Reformasi).

${ }^{19}$ Zuly Qodir, Gerakan Sosial Islam..., 91. 
involve in this movement are mostly from middle class. We can say that Majelis Dzikir led by Arifin Ilham as one of the example.

The next type of Muslims is progressive Muslim. This group has a strong commitment to a fundamental social change in the community by doing social community activism in society transformation. Humanity is a priority for these group movements. Many Islamic groups have Islamic transformative and liberative paradigm which they adopt from pedagogical awareness and liberative theology in Christianity.

Moderat Muslims is the dominant groups in Indonesia since NU and Muhammadiyah followers are included in this group. ${ }^{20}$ The basic landscape of Muslims in Indonesia is actually moderate, not monolithic and democratic. ${ }^{21}$ As moderate Muslims, they are open-minded, friendly, and respecting pluralism and peace. Moderate Muslims, in this Indonesian context, mostly try to show Islam using dialogues and a persuasive approach other than violence.

The next group is radical Islam or people may call it fundamental Islam or literal Islam also. Those that can be included in radical Muslims are Muslims who understand sacred texts literally so that they forbid hermeneutics, pluralism and secularism in Islam. For them, Islam is a perfect religion since its revelation so that it does not need to be interpreted in various ways. What we need is to believe and implement all its commands and abstain from its bans. Whoever tries to interpret al Qur'an are people who always try to find Islam's shortage, whereas Al Qur'an has no shortages at all and Islam is a complete and distinguished religion. The groups want to have an ideal era like the Prophet's era and they are usually known as "salafi' group"2.

20Zuly Qodir, Gerakan Sosial Islam..., 92-94.

${ }^{21}$ Syarif Hidayatullah, Islam 'isme-isme'..., 100.

22Zuly Qodir, Gerakan Sosial Islam..., 94. 
The fundamental movement actually has been growing since $1970 \mathrm{~s}$ but it was invisible and people did not recognize them. This movement seems more visible after reformasi era. Groups that can be included in this stream are Hizbut Tahrir Indonesia (HTI), which advocates a panIslamic caliphate, and the Indonesian Mujahidin Council (MMI: Majelis Mujahidin Indonesia), which advocates implementation of Shari'a as a precursor to an Islamic state., the Defender of Islam (FPI: Front Pembela Islam) which is led by Habib Muhammad Rizieq and well known for using violence in doing their amar ma'ruf nahi munkar activities ${ }^{23}$, Salafior wahabi movement which is originally from Saudi Arabia, FKAW] (Forum Komunikasi Ahlus Sunnah Wal Jama'ah) which actively involved in conflicts in Maluku and Poso Sulawesi. Different from politizing Muslim, these fundamental Muslims do not enter into political arena.

In line with Qodir, Hidayatullah ${ }^{24}$ also differentiates Muslims in Indonesia, but through their streams and schools of Islam. He differentiates Muslims in Indonesia into 9 (nine) groups. They are traditional Islam, indigenization of Islam, Liberal Islam, post traditional Islam, radical, fundamental or literal Islam, transformative Islam, modernist or moderate Islam, neo modernist Islam, and inclusive Islam. This categorization is in line with Qodir's categorization.

From all categorizations proposed by those scholars, basically I agree with those categorizations since if we talk about Muslims in Indonesia we cannot clearly cut that one Muslim group is one of the category. Often, some Muslims can be defined into two or three categories, for example Gus Dur, he was a reforming Muslim, but also re-traditionalizing Islam and moderate.

\footnotetext{
${ }^{23}$ Eko Prasetyo, Membela Agama Tuhan: Potret Gerakan Islam dalam Pusaran Konflik Global. Yogyakarta: Insist Press, 2002, 103.

${ }^{24}$ Syarif Hidayatullah, Islam 'isme-isme'..., 100.
} 
Therefore, in this paper, to see the conflicts happened among Muslims in Indonesia, I categorize Muslims in Indonesia in simpler categorization. I see Muslims in Indonesia in three categorizations, conservative, moderate and radical based on their views on Muslim sects which are considered different from mainstream, or usually called "deviant". Conservative groups see deviant as not in line with Islam, they against over the deviant but they do not attack the groups physically. Groups that belong to these are traditional Islam. Moderate groups see deviant as groups that interpret and understand Islamic teaching differently, and they do not attack the groups. Jaringan Islam Liberal, reforming Islam, progressive Muslims and moderate Muslims can be defined into these groups. The last group, radical groups are groups who see deviant as not part of Muslims therefore they should be banned or even diminished. We can mention radical groups like HTI, FPI, MMI, and salafy into this group. Besides that, I also will call out "deviant" as the fourth in Indonesian Muslims discourse.

\section{Deviant Muslims}

Speaking about deviant in Indonesia, we have to understand what is meant by "deviant". The term deviant usually comes up when there is a splinter movement in orthodoxy or mainstream. This splinter movement is a movement that distorted or broke away from orthodoxy.

In the context of Muslims in Indonesia, according to Martin van Bruinessen, the orthodoxy is reoriented by bodies such as the cleric Indonesian Ulema Council (MUI), and Muhammadiyah and Nahdhatul Ulama (NU) ${ }^{25}$. MUI cleric as an institution of government formation is dominated by orthodoxy, so what is declared heretical by

${ }^{25}$ Martin Van Bruinessen, "Sectarian movements in Indonesian Islam: Social and cultural background", Ulumul Qur'an, vol. III, no. 1 (1992): 16-27. 
the MUI will be a reference by the government, though opinions differ between Muhammadiyah or NU. In other words, orthodoxy is understood that the majority of scholars held and sometimes supported by the authorities.

Related to deviant in Indonesia, on 9 November 2007, the Indonesian Ulema Council (MUI) has issued 10 criteria of cult or deviant. If there is one doctrine that has indicated one of the ten criteria, it can be used as the basis to name the group as deviant. Those ten criteria are as follows: (1)Disagrees with the pillars of faith (Faith in God, Angels, Scriptures, the Apostle, End of Days, Qadla and Qadar) and the pillars of Islam (Saying two sentences Shahadah, prayer five times, fasting, zakat,and hajj), (2) Believes and acts outside the teaching of the Qur'an and hadith (3) Believes in a decree that comes after the Qur'an (4) Disputes the authenticity of the Qur'an; (5) Interprets the Qur'an differently from Qur'an principles; (6) Disagrees with hadith as a source of Islamic teaching; (7) Humiliates, despises or looks down on the Prophets and the Messengers; (8) Disagrees that the Prophet Muhammad is the last Prophet and Messenger; (9) Changes, adds, or reduces principles concerning religious rituals that have been set down by sharia, such as 'The hajj (pilgrimage) is not to Mecca', and prayers do not have to be performed five times a day; or finally (10) Claims other Muslims are infidels without justification by sharia, for instance, they are infidels because they do not come from the same Islamic group. ${ }^{26}$

After examining those ten criterias from MUI and looking at the phenomenon on the violence relating to religious issue happening in Indonesia, to make it clear, in this paper I refer "deviant" term from the definition of Majelis Ulama Indonesia.

\footnotetext{
26MUI: 10 (Sepuluh) Kriteria Aliran Sesat from http://www.media-islam.or.id /2007/11/09/ mui-sepuluh-kriteria-aliran-sesat/
} 


\section{The Indonesian Ulema Council (MUI)'s fatwas on Ahmadiyah and their social impacts}

Before going deeper to the conflicts that involved Ahmadiyah with other Muslims in Indonesia, it is important to know about the MUI (Majelis Ulama Indonesia, Indonesia Ulema Council) and its fatwa since many Muslims Indonesia still consider and obey MUI's fatwas, and also, in my opinion, some MUI's fatwas bring about violent conflicts among Muslims themselves. In this part, I will discuss MUI's fatwas on Ahmadiyah which directly and indirectly cause conflicts with violence among Muslims and the conflicts that happened.

The goverment established the MUI in 1975 to control public expression on religious issues, but now it has been an independent organization. It is organized at the national level but there are also at provincial and regencies levels. MUI in national level may issue a fatwa that not all provincial or regencies level might implement the fatwa ${ }^{27}$ and MUI in provincial or regencies may also issue a fatwa based on the situation in their area.

Since its establishment, MUI (both national and provincial) have issued many fatwas related to "deviant" among Muslims. MUI issued a fatwa in 2007 which gives guidelines on determining deviant teachings as have been mentioned above. Some of the guidelines are those that not in line with six core principles of Islam, recognizing a prophet after Muhammad, changing or modifying Islamic rituals like going hajj (pilgrimage) not to Mecca or stating that doing prayer five times daily is not necessary. In October 2007 the MUI declared a minority sect, alQiyadah al-Islamiyah, as deviant because it recognized its founder

27MB. Hooker, Indonesian Islam Social Change Through Contemporary Fatawa. Honolulu: Anlen \& Unwin, 2003, 60-61. 
Ahmad Musadeq as Imam Mahdi ${ }^{28}$. From this fatwa, there are several persons, sects or groups which then were also declared as deviant.

Related to Ahmadiyah, MUI have issued their fatwas about Ahmadiyah twice. The first fatwa was issued on June $1^{\text {st }} 1980$ that pronounces Jemaat Ahmadiyah is outside Islam and a deviant. This fatwa was based on nine books talking about Ahmadiyah, but MUI never clarifies those books to Ahmadiyah Indonesia. Besides that, in 1984 MUI also warned that Ahmadiyah is harmful for the state's order and peacefulness ${ }^{29}$. This first fatwa did not get much attention from the central government and also did not bring a significant number of violence happening toward Ahmadiyah community. Furthermore, Ahmadiyah could still develop and practice their religious activities without any difficulties.

The second fatwa was issued on July $29^{\text {th }}, 2005$ during National Musyawarah VII that asserts the first fatwa MUI about placing Ahmadiyah as a heretic sect and Muslims who join it are considered as infidels. For who are already in Ahmadiyah are suggested to come back to the true Islam. The government has the obligation to ban Ahmadiyah ${ }^{30}$. In this fatwa, MUI attempts to influence and persuade the government in making a policy. It shows that MUI utilizes its influential position to interfere the state. The letter was signed by the Secretary General of the Ministry of Religion, the Assistant Attorney General for Intelligence, and the Director General for National Integration and Internal Politics at the Ministry of Home Affairs. The letter provides guidance for Governors, Regents, Mayors, Heads of the High

\footnotetext{
${ }^{28}$ See International Religious Freedom Report 2009 from BUREAU OF DEMOCRACY, HUMAN RIGHTS, AND LABOR US.

${ }^{29}$ Himpunan Fatwa MUI (The Compilation of fatwa MUI).

${ }^{30}$ Keputusan fatwa Majelis Ulama indonesia No. 11/MUNAS VII/MUI/15/2005.
} 
Court, and Heads of Regional Offices under the Provincial Ministries of Religion throughout the country on proper implementation of the Joint Ministerial Decree (SKB).

\section{The Ahmadiyah movement}

In this section I will briefly explain about the Ahmadiyah faith and Ahmadiyah in Indonesia. The Ahmadiyah was founded by an Islamic scholar named Mirza Ghulam Ahmad in Qadian North India in 1889, who declared himself as the promised Messiah or the Mahdi for Mus$\operatorname{lims}^{31}$. Since the prophet Muhammad is considered as the last prophet for Muslims, mainstream Muslims see the followers of Ahmadiyah as outside of Islam.

The differences between mainstream Muslim and Ahmadis are based on the interpretations of the Qur'an. One of the major differences is the declaration of the Ahmadiyah's founder, Mirza Ghulam Ahmad, as the "second coming" of Jesus Christ or as the Promised Messiah (Mahdi). Ahmadis believe that Jesus Christ did not die on the cross but escaped to Kashmir India and lived there until old age ${ }^{32}$. The Promised Messiah and Mahdi is from Muslims and his coming was signed by natural signs like the occurrence of lunar and solar eclipses in the month of Ramadhan. ${ }^{33}$

The other difference is that Ahmadiyah has a single worldwide leadership under a Caliph as opposed to regional and local leaders of mainstream Muslims. Khilafat means succession; therefore Khalifa (Caliph) means "a successor to a prophet of Allah whose goal is to carry to

\footnotetext{
${ }^{31}$ Sheikh Abdul Hadi \& Akber A Choudry, Who Are Ahmadi Muslims?, Toronto: Ahmadiyya Muslim Jama'at, 1993, 9-16.

${ }^{32}$ The detail story on Prophet Isa according to Mirza Ghulam Ahmad can be found in Syafi R. Batuah, Nabi Isa dari Palestina ke Kashmir, Indonesia: Jema'at Ahmadiyah Indonesia, 1999.

${ }^{33}$ See www.alislam.org/topics/messiah/
} 
completion the tasks of reformation and moral training that were seeded by the Prophet". In selecting the Caliph, Ahmadis believe that just as Allah appoints a Prophet, Caliph or Khalifa is also appointed by Allah through guiding a group of pious believers who choose the most eligible person to become a Khalifa. A Khalifa will lead Ahmadiyah community for the rest of his life as a living testament to Divine Will. ${ }^{34}$

The headquarters used to be in Qadian till 1947 but when there was separation between India and Pakistan they were moved to Rabwah, Pakistan. Due to the persecution in Pakistan, the headquarters was moved to London UK when the fourth Caliph (Mirza Tahir Ahmad) made an exodus to UK in 1984. Now, it is still in London under the fifth Caliph (Mirza Masroor Ahmad).

Around the world, the Ahmadiyah Movement now has built over 10,000 mosques, over 500 schools, and over 30 hospitals in more than 170 countries. It also has translated the Holy Quran into over 60 languages. It also propagates teachings of Islam and the message of peace and tolerance through several medias. It has a twenty-four hour satellite television channel without commercial break called Muslim Television Ahmadiyya (MTA), the Internet and publication. It also has an independent charitable organization, Humanity First, which serves people in disaster areas ${ }^{35}$.

In terms of worship, the Ahmadis follow the five pillars too like other mainstream Muslims. They vow the same shahadat, do sholat the same as other Muslims do, pay zakat, and perform their hajj in Mecca also. Therefore, actually there is no difference at all between Ahmadi and mainstream Muslims in doing obligation as Muslims.

\footnotetext{
${ }^{34}$ See www.alislam.org/topics/about-khilafat.html

${ }^{35}$ See www.alislam.org, the official website of the Ahmadiyya Muslim Community
} 
From the explanation above, we can see that Ahmadiyah movement is an international religious organization with all its members who embrace Ahmadi identity.

Discussing Ahmadiyah in Indonesia, Ahmadiyah first came into Indonesia in 1925 when a muballigh named Maulana Rahmat Ali HAOT came to Tapak Tuan Aceh. Therefore, Ahmadiyah has been existed in Indonesia for more than 90 years. It has legally registered in Law Ministry since 1953 , March $13^{\text {th }} 1953$ No. JA 5/23/13 and in additional state news (tambahan berita Negara RI) no 26, March 1953. And then changed in Berita Negara No. 3. 1989; and additional State News No. 65 date 15 August 1989.

Ahmadiyah's headquarter is in Parung Bogor, West Java. Nowadays, it has more than 250 branches which spread out in Indonesia with about 600.000 members, and most of the branches are in West Java. ${ }^{36}$

Ahmadiyah community is a minority Muslim group among mainstream Muslims in Indonesia. Its different interpretation on 'khataman nabiyyin'makes it seen as a heretical sect in Islam. Even some mainstream Muslims accuse it as outside Islam, so if Ahmadiyah claims to be Muslims, it means that Ahmadiyah blots Islam. In relating to Ahmadiyah, as have been mentioned before, Majelis Ulama Indonesia (The Indonesian Council Ulama) have issued edict saying that Ahmadiyah as deviant twice, in June 1980 and July 2005. Unfortunately, the addict issued lead to violence toward Ahmadiyah followers in Indonesia.

\section{Violent conflicts toward Ahmadiyah}

The conflicts and violence that happened to Ahmadiyah cannot be separated with the issuing a fatwa from MUI. As has been mentioned

${ }^{36}$ Iskandar Zulkarnain, Gerakan Ahmadiyah di Indonesia, Yogyakarta: LKiS, 2005, 290. 
before that MUI has issued their fatwas about Ahmadiyah twice. However, the number of violence toward Ahmadiyah increased dramatically after the second fatwa in 2005.

After reviewing conflicts that involved Ahmadiyah, I divide the conflicts into three types. They are: issuing decree on banning Ahmadiyah, sealing the mosques and banning of doing religious activities, and the last one is mobbing the mosques and houses, including killing.

In its annual report ${ }^{37}$, CRCS reported that there were 20 violence toward Ahmadiyah community in 2008 which can be categorized into 4 categories; destruction on moques and musholla, destruction on nonworship place assets, sealing mosques and musholla and sealing nonworship place assets. ${ }^{38}$

Setara Institute reported that there were 193 violations toward Ahmadiyah in 2008. There were 145 incidents before the issuing of SKB and 48 incidents after it. And the most incidents happened in West Java in which many Ahmadis live ${ }^{39}$.

In 2001, the local Government of West Lombok issued SKB Bupati4 that prohibits Ahmadiyah to be exist in West Lombok. Because of this letter, in Sambielen Lombok West Nusa Tenggara, a mosque was burnt, Ahmadis' houses were destroyed, an Ahmadi, Papu Hasan was killed

\footnotetext{
${ }^{37}$ CRCS, Laporan Tahunan Kehidupan Beragama di Indonesia tahun 2008, 11.

${ }^{38}$ In June 13th 2008 thousand people and 14 Islamic organizations sealed Jemaat Ahmadiyah Secretariat in Jl Perintis Kemerdekaan Bogor. Juni 18th 2008, about 100 people sealed six mosques in Sukadana dan Penyairan village Campaka, Cianjur.

June 20th 2008, FPI (Front Pembela Islam) South Sulawesi sealed Nusrat Mosque and Ahmadiyah secretariat and in Cianjur, hundreds people from Hisab and Garis sealed al Ghafur mosque in Jl Muwardi Cianjur West Java by "Disegel Umat Islam"(sealed by Muslims) writing in red paint. There were no security apparatus present.

${ }^{39}$ Ismail Hasani (ed.), Berpihak dan Bertindak Intoleran: Intoleransi Masyarakat dan Restriksi Negara dalam Kebebasan Beragama/Berkeyakinan di Indonesia/. Jakarta: Publikasi SETARA Institute, 2009.

${ }^{40}$ Keputusan Bupati Lombok Barat No. 35 Tahun 2001.
} 
and their properties were looted. While in Lombok Timur, in September 2002, The Regent issued a handbill restricting of spreading Ahmadiyah teachings in Lombok Timur ${ }^{41}$. In 2004, Regent of Lombok Timur issued a decree (Surat Keputusan) about banning Ahmadiyah in East Lombok resulted in ruining three mosques in Pancor by people.

In Kuningan, SKB (Surat Keputusan Bersama) was issued by Kuningan local government that banned Ahmadiyah in November 2002. As a result, eight mosques and houses were wracked. In December 2004, again the regent of Kuningan, in collaboration with the attorney and religious department of Kuningan issued SKB banning Ahmadiyah in Kuningan. ${ }^{42}$ In the following year, after the issuing of SKB in Kuningan, there was much violence toward Ahmadiyah community in that area. ${ }^{43}$

On Wednesday September 28th 2005, Cianjur's leaders prohibit Ahmadiyah from doing their religious activities. They were Regent Wasidi Swastomo, Attorney Deddi Siswadi, and Ajun Komisaris Besar Anang Suhardi from Police department by signing a SKB ${ }^{44}$. Religious Department West Nusa Tenggara officially banned Ahmadiyah in West Nusa Tenggara in Thursday, October $27^{\text {th }} 2005^{45}$.

\footnotetext{
${ }^{41}$ Surat Edaran Bupati Lombok Timur No.: 045.2/134/KUM/2002.

${ }^{42}$ Keputusan Bersama Bupati Kuningan, Kepala Kejaksaan Negeri Kuningan, Kepala Kantor Departemen Agama Kabupaten Kuningan No.:451.7/KEP.58-Pem.Um/2004, No.:KEP-857/02.22/ Dsp.5/12/2004, No.: Kd.10.08/6/ST.03/147/2004.

This SKB was followed by many violence toward Ahmadiyah community in Kuningan.

${ }^{43}$ On October 20 ${ }^{\text {th }}$ 2004, two musholas named At Takwa in Dusun 1 and Al Hidayah in Dusun IV in Manislor were destroyed by 10 people dressing ninja who came by a minibus. They arrived at 21.00 and directly broke window glasses in At Takwa and then moved to Al Hidayah. In $\mathrm{Al}$ Hidayah, they broke the windows, the roof and burnt carpet.( http://majalah.tempointeraktif.com/ id/arsip/2004/10/25/PST/mbm.20041025.PST92832.id.html). On Friday July 29th 2005, Kuningan local government closed mosques and musholas in Manislor, Jalaksana sub district. In Kuningan, particularly in Manislor, majority people are Ahmadis, only some families that are not Ahmadis. An Nur mosque, seven musholas and Fadhal Umar hall that is usually used by Ahmadis to do their activities were closed and they set barriers on their doors, and windows. It was done under the agreement between muspida (local leaders) and Ahmadiyah leaders.( http://www.tempo.co.id/ hg/nusa/jawamadura/2005/07/29/brk,20050729-64587,id.html)

${ }^{44}$ http://www.tempo.co.id/hg/nusa/jawamadura/2005/09/28/brk,20050928-67225,id.html

${ }^{45}$ http://www.tempo.co.id/hg/nusa/nusatenggara/2005/10/27/brk,20051027-68620,id.html
} 
In 2008, central government issued SKB (joint ministerial decree on the Ahmadiyah) no 3 year 2008, no:KEP-033/A/JA/6/2008 that warns Ahmadis and other people. The SKB was as the response the calls to restrict the group's roghts. For the most part, Ahmadiyah followers were allowed to continue worshiping, but they were not free to proselytize or otherwise practice their faith publicly.

In South Sumatra, several conservative groups under the umbrella organization Islamic People's Forum (FUI), including the Islam Defenders Front (FPI) and the Indonesian Mujahidin Council, along with Hizbut Tahrir Indonesia, insisted the dissolution of the Ahmadiyah. As a result, in September 2008 the acting Governor of South Sumatra issued a governor's decree banning Ahmadiyah. It stated that "the Ahmadiyah would be prohibited in the province because Ahmadiyah is not compatible with Islamic teachings." Many Muslims supported this ban, including officials from the provincial offices of the Ministry of Religious Affairs, local prosecutors, and representatives from the local MUI and other Islamic organizations, including academics from Palembang-based Raden Fatah State Islamic Institute. The governor was only in power for three months. The Ahmadiyah community is still able to perform its usual and normal religious activities in that province ${ }^{46}$. And on October $5^{\text {th }}$ 2008, Mahoto Mosque in Tanjung Medan, Pujud, Rokan Hilir Riau was destroyed. 47

Those are some rules and regulations issued by the government both the central and regional that were directly influenced by the issuing fatwa from MUI on Ahmadiyah and also demand from other Muslim communities who do not agree with Ahmadiyah's belief.

\footnotetext{
${ }^{46}$ International Religious Freedom Report 2009 from BUREAU OF DEMOCRACY, HUMAN RIGHTS, AND LABOR US.

${ }^{47}$ CRCS, LaporanTahunan Kehidupan Beragama di Indonesia tahun 2008, 12.
} 
Other conflicts faced by Ahmadiyah are in terms of restriction of doing religious activities. There were some which happen around Indonesia. For example, June $20^{\text {th }}$ 2008, FPI (Front Pembela Islam) South Sulawesi sealed Nusrat Mosque and Ahmadiyah secretariat and in Cianjur, hundreds people from Hisab and Garis sealed al Ghafur mosque in Jl Muwardi Cianjur West Java by "Disegel Umat Islam"(sealed by Muslims) writing in red paint. There were no security apparatus present.

Chep Hernawan, the leader of Garis Cianjur stated that that sealing was done because Ahmadiyah does not stop their activities although SKB prohibits them to do religious activities and spread their teachings. A day before, there were four Ahmadis in Parakansalak Sukabumi who were forced to declare their coming out from Ahmadiyah witnessed by local MUI, police officers and the local government.

Five days after, on June $25^{\text {th }}, 2008$ hundreds people came into House of Representative office in Cianjur and complained about the removal of sealing signs in the Ahmadiyah's mosques. They accused The Cianjur Police, Ajun Komisaris Pramono has given permission to Ahmadiyah to do it. They argued that removing those sealing signals indicated that Ahmadiyah did not obey SKB. Whereas the police officers represented by Muhibudin stated that police will always play their role in protecting the society and he promised that they would deal with that problem further ${ }^{48}$.

Still in Cianjur, a group of hardliners sealed a small Ahmadiyah mosque in Talaga village and a mosque in Parabon village, on August 1, 2008. On August $8^{\text {th }} 2008$, people wrecked Baiturrahman mosque and mushola Baitud Do'a in Kebon Muncang and Kebon Kelapa, Parakansalak Sukabumi. Still in the same month, on August $19^{\text {th }}$ 2008, about 200

\footnotetext{
${ }^{48}$ http://www.tempointeraktif.com/hg/nusa/2008/06/25/brk,20080625-126674,id.html Penghapusan Segel Masjid Ahmadiyah Diprotes
} 
people belong to Forum Masyarakat Muslim Ciputat (Ciputat Muslim Community Forum) sealed Baitul Qoyyum mosque in Jl Raya Bukit Indah Ciputat, Tangerang Banten. The FMMC believed that Ahmadiyah members had failed to abide by a joint ministerial decree released in June that banned the group from proselytizing. Police thwarted the residents' attempt to seal the mosque.

On August 27, 2008, hundreds of FPI members threatened the Ahmadiyah congregants of Al Mubarak mosque in Jagakarsa, South Jakarta, and demanded they cease all of their activities before the month of Ramadan.

The last kind of conflicts faced by Ahmadiyah are violence like mobbing houses, mosques and even killing. In this paper, I present some of them just to give description on how it happened and how the government dealt with that violence.

In July $9^{\text {th }}$ 2005, Mubarak building that is the headquarter of Ahmadiyah was attacked by thousands people. At that time Ahmadiyah followers were holding national annual gathering namely "Jalsah Salanah". The mass forced them to stop the activities. Consequently, Jalsah was ended earlier and almost all participants went home for their safety. A week after, thousands people came again to Mubarak building on July $15^{\text {th }} 2005$ and asked Ahmadis to get out of there. Finally, about 200 Ahmadis were evacuated by the police to the attorney office in Cibinong 49 .

On Friday 22 July 2005, tens member of Umat Islam Indonesia (UII) led by Habib Abdurrahman Assegaf came again to Mubarak building in Kemang. They said that they were monitoring whether Ahmadis still doing their activities or not. They threatened if Ahmadis still do their activities they would bring 15 thousands of people to attack

${ }^{49}$ http://www.tempo.co.id/hg/jakarta/2005/07/15/brk,20050715-63963,id.html 
Ahmadis. There were 100 police officers and 30 satpol PP guarding the building before they came. There were also people from Komisi Nasional HAM (National Commission for human rights) led by MM Billah. After the mass dispersed, two buses hired by the police arrived and picked Ahmadiyah's things to a safe place ${ }^{50}$.

The Ahmadiyah community of 182 individuals living in camps as internally displaced persons (IDPs) in West Lombok since their homes and mosques were attacked by a mob in 2006 continued to face challenges during the reporting period. On April 14, 2009, the local government requested that the IDPs cancel plans to return to their homes in Gegerungan Village due to continuing security concerns and pending compensation issues. The April request followed an earlier series of requests in March that the Ahmadiyah delay their plans to return. So far, four families have returned to Gegerungan Village. They are reportedly living and working there safely, although sometimes they still face low level intimidation from the local community. Until today, there are still some mosques belong to Ahmadiyah community which are sealed or closed even mobbed by other Muslims.

Looking at conflicts and violence experienced by Ahmadiyah community in Indonesia, we can say that the conflicts will likely appear between Ahmadiyah community and other Muslims who do not agree with Ahmadiyah's belief in the future. However, violence conflicts actually can be eliminated if all parties that involved in the conflict try hard to manage the conflict into more constructive conflict.

The government, as the authoritative, seems to take the easiest way for them to deal with the conflicts by issuing decree that mostly suppress the group that are accused of being deviant. Furthermore,

${ }^{50 h t t p: / / w w w . t e m p o i n t e r a k t i f . c o m / h g / j a k a r t a / 2005 / 07 / 22 / b r k, 20050722-64253, i d . h t m l ~}$ 
the decree or the law issued by the State are mostly not effective to control the conflict even it becomes a justification for some Muslims groups to attack what so called "deviant" group without any afraid of being sent to the jail. Most people who attack 'deviant" group can live freely after destructing other groups' properties.

\section{Ahmadiyah case: between Indonesia and Malaysia}

In order to see how Ahmadiyah's issue is dealt by the state, in this part I try to see how Ahmadiyah is treated in other country, Malaysia.

Officially, the state government of Malaysia has been recognized Ahmadiyah as "non Muslims" therefore they can still practice their religious activities without any subjection from the state ${ }^{51}$.

In Malaysia, actually Ahmadiyah's community face the same problem as Ahmadiyah in Indonesia. They are targeted both by the society and the state. The state government recognizes Ahmadiyah/Qadiani as non Muslim. The Selangor fatwa council in 1975 decreed that Ahmadis were not Muslims, and they recommended that their special Malay privileges be removed. As result they can practice their religious activity freely.

The opposition against the movement started shortly after the movement was introduced to Malaya by an Indian missionary in the 1930s. Selangor Executive Council Chairman for religious affairs Hasan Mohammed Ali in December 2008 stated that the state government was looking into compulsorily taking the Baitussalam land belongs to Ahmadis. Finally in April 2009 the Selangor Islamic Religious Council (MAIS) issued a directive forbidding Ahmadis from using their mosque in Kampong Nahkoda for Friday prayers. Those who disobeyed this

${ }^{51}$ See Nur Aminah- Rosidi Semail in Pengalaman Malaysia menangani Konflik Agama in http"/ /hidayatullah.com/read/15445/19/02/2011/pengalaman-malaysia-menangani-konflik-agama-/html 
order could be subject to a fine and imprisonment. ${ }^{52}$

Similarly to Indonesians ulamas, a few religious Muslims leaders were proposing to the state to change Ahmadis identity MyKad to "Qadiani" instead of "Muslim". Even some religious leaders were also provoking other Muslims to act against Ahmadis during their speeches. However, physical violence against Ahmadis was not heard till now. They have their own ways in insulting Ahmadis, like throwing feces into Ahmadi's house, shouting "astaghfirulloh or sesat (infidels) when they meet Ahmadis, or not replying Ahmadis' salam/greeting. ${ }^{53}$

Comparing to Indonesia, we can say that although Ahmadiyah there face opposition from the state and also other Muslims, Ahmadis in Malaysia do not experience violence like in Indonesia because the state and the citizens really do the law enforcement. If there is someone who breaks the rules like doing criminals they will get the consequences based on the law. It is far different from what is happening in Indonesia, many people who attacked and did violence toward Ahmadiyah are free and not afraid of being sent to the jail of their crime. It is because of the weak law enforcement in Indonesia.

The state tends to be more carefully in dealing with Ahmadiyah case in terms of legal status of Ahmadiyah, by not banning Ahmadiyah constitutionally but staying at status quo using SKB issued in 2008. However, it is not followed by strong commitment to protect and treat Ahmadis justly. State government let regional governments to deal with Ahmadiyah issue in their region. Therefore, some local government issued banning on Ahmadiyah's acitivities. ${ }^{54}$

\footnotetext{
${ }^{52}$ http://thepersecution-org.blogspot.com/2011/11/malaysias-ahmadis-livingdangerously.html, accessed $7^{\text {th }}$ March 2012

${ }^{53} \mathrm{http}: / /$ thepersecution-org.blogspot.com/2011/11/malaysias-ahmadis-livingdangerously.html, accessed $7^{\text {th }}$ March 2012

${ }^{54}$ See Laporan Tahunan CRCS 2011, 36-40.
} 
In general, conflicts among Muslims in Indonesia, particularly with Ahmadiyah after reformasi era were caused by theological reasons, different interpretation on Al Qur'an and hadits, and mostly is on the discourse of heresy and blasphemy. Besides that, accused of or being exclusive also become one of the reasons of conflicts. The conflicts are not simply between minority and majority. When we examine, we find out that MUI as an authorized ulama institution who think that they have rights of judging Muslims on true Muslims or not with their fatwas, are mostly in conflicts and cause the conflicts with violence although they always deny that. Their eagerness to evaluate any sects or Muslims groups' beliefs and worship practices and decide which group is heretic which one is not; indirectly give justification for other Muslims to do violence towards the groups which are accused of being heretic or doing blasphemy.

Muslims groups which tend to start conflicts by attacking Muslims groups accused as heretic are FPI, FUI and several small and local groups which are tend to be hardliners or radical. In addition, sometimes the conflicts happened between people or Muslims in neighborhood who feel annoyed by the existence of a "different" group in their community. Those Muslims are usually moderate and conservative ones.

Conflicts faced by Ahmadiyah do not happen in all areas in Indonesia, although it faces opposition from almost all Muslim groups in Indonesia, they who live in West Java that face violence from other Muslims group and also from the local government. However, Ahmadiyah community in other province like in Central Java and Yogyakarta find it easy to live together and mingle with other Muslim groups without any crucial conflicts although their neighborhood knows about their differences. 


\section{Concluding remarks}

Conflicts among Muslims in Indonesia is common phenomena lasting for years since the nature of Muslims in Indonesia which very diverse. The conflicts that lay on the difference interpretation and practice, in fact enrich Indonesia as long as those conflicts do not head to violence. However, since reformasi era, the conflicts raise dramatically because of the new freedom got by people and unfortunately, most of those conflicts turn to violence that bring about casualties.

Looking back at the conflicts involved Ahmadiyah community that happened in the period between 2000-2011, we can say that conflicts with violence appear because of different religious interpretation and practice among Muslims and those differences are used to see other Muslims as heretic or deviant so that they can be condemned.

Muslims, both personal and groups which are accused as deviant, heretic or exclusive mostly become target of violence from other Muslims. Muslim groups which experienced conflicts with violence usually are seen as "different", or exclusive among others. Whereas Muslim group which become perpetrators or actors of violence range from common Muslims (conservative and moderate) into radical groups.

The government, as the authoritative, in many cases seems to give less attention on the conflicts among Muslims. Even more, the government seems to omit the violence that occur and the worst thing is that the government itself commits violence toward Muslims groups accused as deviant or heretics by issuing a decree which discriminate or oppress those groups.

Observing the nature of Muslims diversities and the conflicts among them in Indonesia, in my opinion, conflicts have two sides, positive and negative ones. Since we cannot avoid those differences and conflicts, we can utilize them to bring positive impact into this nation. 
The way we manage the conflict will really determine the future of this state. The next question is then how to resolve the conflict through conflict resolution and how to involve all people regardless their streams and gender in conflict resolution process.

\section{Bibliography}

Bagir, Zainal Abidin and Cholil, Suhadi. Potret Pluralisme di Indonesia: Kajian Literature Atas Wacana dan Praktik Pluralism 1998-2007. Yogyakarta: Center of Religious and Cultural Studies Gadjah Mada University, 2008.

Batuah, Syafi R. Nabi Isa dari Palestina ke Kashmir. Indonesia: Jema'at Ahmadiyah Indonesia, 1999.

Bruinessen, Martin Van "Sectarian movements in Indonesian Islam: Social and cultural background", Ulumul Qur'an, vol. III, no. 1 (1992): 16-27.

CRCS. Laporan Tahunan Kehidupan Beragama di Indonesia tahun 2008. Fauzi, Ihsan Ali, Alam, Rudy Harisyah, and Panggabean, Samsu Rizal, "Pola-Pola Konflik Keagamaan di Indonesia (1990-2008)", Laporan Penelitian. Yayasan Wakaf Paramadina, Magister Perdamaian dan Resolusi Konflik, Universitas Gadjah Mada (MPRK UGM), The Asia Foundation (TAF), 2009.

Geertz, Clifford. The Religion of Java. New York: Free Press, 1960. Madjid, Nurcholish, "Agama dan Masyarakat", in AW Widjaya (Ed.). Manusia Indonesia, Individu, Keluarga dan Masyarakat. Jakarta: Akademik Pressindo, 1986.

Hadi, Sheikh Abdul \& Choudry, Akber A. Who Are Ahmadi Muslims? Toronto: Ahmadiyya Muslim Jama'at, 1993. 
Hasani, Ismail (ed.). Berpihak dan Bertindak Intoleran: Intoleransi Masyarakat dan Restriksi Negara dalam Kebebasan Beragama/ Berkeyakinan di Indonesia. Jakarta: Publikasi SETARA Institute, 2009.

Hidayatullah, Syarif. Islam 'isme-isme', Aliran dan Paham Islam di Indonesia. Yogyakarta, Pustaka Pelajar, 2010.

Himpunan Fatwa MUI (The Compilation of fatwa MUI).

Hooker, MB. Indonesian Islam Social Change Through Contemporary Fatawa. Honolulu: Anlen \& Unwin, 2003.

International Religious Freedom Report 2009 from BUREAU OF DEMOCRACY, HUMAN RIGHTS, AND LABOR US.

Keputusan Fatwa Majelis Ulama indonesia No. 11/MUNAS VII/MUI/ 15/2005.

Keputusan Bupati Lombok Barat No. 35 Tahun 2001.

Keputusan Bersama Bupati Kuningan, Kepala Kejaksaan Negeri Kuningan, Kepala Kantor Departemen Agama Kabupaten Kuningan No.:451.7/KEP.58-Pem.Um/2004, No.:KEP-857/02.22/Dsp.5/12/ 2004, No.: Kd.10.08/6/ST.03/147/2004.

Panggabean, Samsu Rizal et. al., "The Patterns of Religious Conflict in Indonesia (1990-2008)", Studia Islamika, Indonesian Journal for Islamic Studies, vol 17, Number 2 (2010): 239-298.

Prasetyo, Eko. Membela Agama Tuhan: Potret Gerakan Islam dalam Pusaran Konflik Global. Yogyakarta: Insist Press, 2002.

Qodir, Zuly. Gerakan Sosial Islam: Manifesto Kaum Beriman. Yogyakarta: Pustaka Pelajar, 2009.

Rahmat, M. Imdadun et. al. Islam Pribumi Mendialogkan Agama Membaca Realitas. Jakarta: Penerbit Erlangga, 2003. 
Ricklefs, M.C. "Religion, politics and social dynamics in Java: Historical and contemporary rhymes", presented as keynote speech in Indonesia Update (7 September 2007), Australia.

Suparlan, Parsudi, "Preface" in Roland Robertson (ed.). Agama Dalam Analisa dan Interpretasi Sosiologi. Jakarta: Rajawali Press, 1986.

Surat Edaran Bupati Lombok Timur No.: 045.2/134/KUM/2002.

Woodward, Mark, "Religious Conflict and the Globalization of Knowledge in Indonesian History", in Linell. E. Cady and Sheldon W. Simon (eds.). Religion and Conflict in South and Southeast Asia: Disrupting Violence, London: Routledge, 2007.

Zulkarnain, Iskandar. Gerakan Ahmadiyah di Indonesia, Yogyakarta: LKiS, 2005.

\section{Internets}

http://sp2010.bps.go.id/index.php/site/tabel?search-tabel= Penduduk+Menurut+Kelompok+Umur+dan+Agama+yang+ Dianut\&tid $=320 \&$ search-wilayah $=$ Indonesia $\&$ wid $=0000000000 \&$ lang=id, accesed February 20 2012.

http://islamlib.com/id/halaman/tentang-jil

http://www.media-islam.or.id /2007/11/09/mui-sepuluh-kriteria-aliransesat/ MUI: 10 (Sepuluh) Kriteria Aliran Sesat

http://majalah.tempointeraktif.com/id/arsip/2004/10/25/PST/ mbm.20041025.PST92832.id.html).

http://www.tempo.co.id/hg/nusa/jawamadura/2005/07/29/ brk,20050729-64587,id.html)

http://www.tempo.co.id/hg/nusa/jawamadura/2005/09/28/ brk,20050928-67225,id.html 
http://www.tempo.co.id/hg/nusa/nusatenggara/2005/10/27/ brk,20051027-68620,id.html http://www.tempo.co.id/hg/jakarta/2005/07/15/brk,2005071563963,id.html

http://www.tempointeraktif.com/hg/jakarta/2005/07/22/brk,2005072264253,id.html http://www.tempointeraktif.com/hg/nusa/2008/06/25/brk,20080625126674,id.html Penghapusan Segel Masjid Ahmadiyah Diprotes http://thepersecution-org.blogspot.com/2011/11/malaysias-ahmadis-living-dangerously.html, accessed $7^{\text {th }}$ March 2012 http://thepersecution-org.blogspot.com/2011/11/malaysias-ahmadis-living-dangerously.html, accessed $7^{\text {th }}$ March 2012

Nur Aminah-Rosidi Semail in Pengalaman Malaysia menangani Konflik Agama in http"//hidayatullah.com/read/15445/19/02/2011/ pengalaman-malaysia-menangani-konflik-agama-/html www.alislam.org/topics/messiah/ www.alislam.org/topics/about-khilafat.html www.alislam.org, the official website of the Ahmadiyya Muslim Community, 